DOI: https://doi.org/10.33330/jurteksi.v6i1.429

Available online at http://jurnal.stmikroyal.ac.id/index.php/jurteksi

\title{
IMPLEMENTASI SISTEM PAKAR UNTUK MENDIAGNOSIS DEMAM TIFOID DAN SARAN PENANGGULANGANNYA
}

\author{
Fauriatun Helmiah $^{1 *}$, Nurwati ${ }^{1}$, Dewi Maharani ${ }^{1}$ \\ Program Studi Manajamen Informatika Stmik Royal Kisaran \\ Email:*fahel_mi2@yahoo.com
}

\begin{abstract}
Abstarct: Typhoid fever is an acute infectious disease that occurs in the human digestive tract (especially the small intestine) caused by salmonella tyhpi, in different phases the bacteria can spread to the bloodstream and even to the human bones. So with this disease detection needs to be done since. This research builds an expert system to diagnose typhoid fever with a backward chaining method with an inference process so that it can be used to produce disease diagnoses based on perceived symptoms and provide appropriate solutions.
\end{abstract}

Keywords : Expert System, Backward Chaining, Thypoid Fever

\begin{abstract}
Abstrak: Demam Tifoid adalah penyakit infeksi akut yang terjadi pada saluran perncernaan manusia (terutama usus halus) yang disebabkan oleh bakteri salmonella tyhpi, pada fase berbeda bakteri dapat menyebar ke aliran darah bahkan ke tulang manusia. Maka dengan ini perlu pendeteksian penyakit sejak ini. Penelitian ini membangun sistem pakar untuk mendiagnosis penyakit demam tifoid dengan metode backward chaining dengan proses inferensi agar dapat digunakan untuk menghasilkan diagnosa penyakit berdasarkan gejala yang dirasakan serta memberikan solusi yang tepat.
\end{abstract}

Kata kunci: Sistem Pakar, Backward Chaining, Demam Tifoid..

\section{PENDAHULUAN}

Di era teknologi informasi sekarang ini, komputer bukan lagi digunakan untuk membantu pekerjaan manusia, tapi bahkan untuk menggantikan pekerjaan manusia yang tidak memerlukan pemikiran dan bersifta rutinitas. Perkembangan selanjutnya, para ahli mencoba untuk menirukan sistem kerja otak manusia, sehingga diharapkan suatu saat nanti mungkin akan tercipta suatu komputer yang dapat menimbang dan mengambil keputusan sendiri, sebagaimana layaknya manusia. Oleh karena hasil kerja sistem komputer ini harus diakui lebih cepat, teliti dan akurat dibandingkan dengan manusia. Hal inilah yang mendorong lahirnya teknologi AI (Artificial Inteligence) yang salah satu cabangnya adalah sistem pakar (expert system)[1]. Sistem pakar merupakan program komputer yang meniru proses pemikiran dan pengetahuan pakar untuk menyelesaikan suatu masalah yang spesifik. Salah satu implementasi sistem pakar 
DOI: https://doi.org/10.33330/jurteksi.v6i1.429

Available online at http://jurnal.stmikroyal.ac.id/index.php/jurteksi

ini adalah di bidang kedokteran, di mana sistem pakar dipakai untuk mendiagnosis suatu penyakit. Pendiagnosis penyakit ini menggunakan pengetahuan dan prosedur inferensi dari dokter sebagai pakar pakar. Di mana pengetahuan-pengetahuan yang dimiliki oleh dokter, kemudian disimpan ke dalam satu program komputer yang diharapkan memiliki hasil kerja yang berjalan sebagaimana layaknya penalaran yang dilakukan oleh seorang dokter pada saat mendiagnosis penyakit. sistem pakar ini akan digunakan untuk menggantikan peran dokter sebagai pendiagnosis sementara, khususnya demam tifoid.

Penyakit tifoid adalah jenis penyakit infeksi saluran pencernaan yang sering dijumpai. Jenis ini bukan hanya menyerang anak-anak saja, tapi dapat menyerang orang dewasa, di mana bisa terjadi komplikasi atau menyebabkan kematian bila tidak cepat diobati[2].

Metode yang digunakan untuk merancang suatu sistem pakar yang bisa digunakan untuk mendiagnosis penyakit adalah metode backward chaining. Di mana dengan metode ini dimulai dengan mengumpulkan semua gejalagejala penyakit demam tifoid yang menjadi basis pengetahuan, kemudian diolah ke dalam mesin inferensi yang digunakan sebagai dasar pengambilan keputusan untuk menentukan hasil diagnosanya, dan memberikan saran penanggulangannya[3].

\section{METODE}

\section{Akuisisi Pengetahuan}

Sebuah pengetahuan sistem pakar berbasis pengetahuan dapat menirukan apa yang dapat dilakukan oleh seorang pakar. Pengetahuan dikumpulkan untuk membangun sebuah sistem pakar. Akuisis pengetahuan adalah proses pengumpulan pengetahuan, pemindahan da perubahan bentuk pemecahan masalah (problem solving) keahlian dari pakar atau sumber dokumen-dokumen pengetahuan yang dimasukkan ke dalam program komputer untuk pembuatan dan pengembangan dari basis pengetahuan.

Sumber-sumber yang potensial dijadikan sumber pengetahuan, di mana dalam hal ini dokter, khususnya yang berhubungan dengan pengetahuan tentang penyakit demam tifoid. Proses pengumpulan pengetahuan dari seorang pakar merupakan tugas yang rumit dan tidak mudah yang sering menimbulkan kendala atau hambatan dalam pembuatan sistem pakar.

\section{Representasi Pengetahuan}

Representasi pengetahuan adalah metode yang digunakan untuk pengkodean pengetahuan (knowledge base) dalam sistem pakar. Dalam penulisan skripsi ini digunakan metode representasi pengetahuan dengan metode kaidah produksi (production rule) [4].

Kaidah produksi ini dipilih untuk merepresentasikan pengetahuan karena mempunyai keuntungan sebagai berikut

1. Kaidah produksi berbentuk modular sehingga mempunyai fleksibilitas yang memungkinkan setiap kaidah dapat dimodifikasi dengan mudah.

2. Kaidah produksi merupakan jenis representasi pengetahuan yang mudah untuk diinterpretasikan. 
DOI: https://doi.org/10.33330/jurteksi.v6i1.429

Available online at http://jurnal.stmikroyal.ac.id/index.php/jurteksi

3 Kaidah produksi menirukan cara berpikir manusia untuk menyelesaikan masalah dan Kaidah produksi sangat berguna untuk membuat representasi pengetahuan deklaratif.

Diagnosis berisi informasi tentang kesimpulan penyakit yang diderita pasien yang diambil berdasarkan gejalagejala yang dirasakan pasien. Kemudian data diagnosis ini disimpan pada data pasien.

\section{HASIL DAN PEMBAHASAN}

Dalam hal ini penulis akan menjabarkan tentang langkah-langkah pembuatan program hingga implementasi yang dilakukan dalam menyelesaikan rancangan sistem pakar untuk mendiganosis demam tifoid ini adalah sebagai berikut:

1. Menyelesaikan Desain Sistem

Dimana penulis harus menyiapkan

Data Flow Diagram, Pohon Keputusan, Model Input dan Output untuk sistem pakar untuk mendiganosis demam tifoid yang menjadi objek penelitian.

2. Menyediakan Perangkat Keras (Hardware) dan Perangkat Lunak (Software)

Tahapan ini merupakan tahapan dimana penulis harus menyediakan segala perangkat-perangkat lunak diantaranya ssitem operasi komputer, bahasa pemrograman yang digunakan dan perangkat keras yang dibutuhkan.

3. Menuliskan Listing Program ke Komputer

Pada saat perangkat lunak (software) dan perangkat keras (hardware) komputer telah dipersiapkan, maka penulis akan menyalin atau mengetikkan instruksi-instruksi (listing) rancangan sistem ke komputer sesuai dengan bahasa pemograman yang digunakan.

4. Menguji Sistem

Tahapan ini merupakan suatu langkah yang ditujukan untuk mengevaluasi apakah sistem yang telah dibuat sesuai dengan prosedurprosedur yang telah ditetapkan.

5. Mendapat Persetujuan

Meminta persetujuan dari pihak yang akan memakai sistem atau yang berhak memberikan verifikasi atas kebenaran hasil output sistem yang dirancang, di mana dalam hal ini adalah dokter sebagai pakar yang digunakan dalam penelitian ini, yaitu untuk mengetahui sistem ini sudah sesuai dengan apa yang diinginkan dan dibutuhkan atau tidak.

6. Melakukan Bimbingan Terhadap langkah-Langkah Pengoperasian Sistem

Pada tahapan ini, penulis melakukan beberapa panduan tentang pengoperasian sistem kepada operator atau personil yang dipilih oleh pihak pengguna program, yaitu user.

7. Perawatan Sistem (Maintenance) Walaupun sistem yang diterapkan sudah berjalan dengan baik, perawatan (maintenance) terhadap sistem merupakan suatu hal yang tidak kalah pentingnya untuk dilakukan. Tanpa adanya perawatan terhadap sistem, sistem tidak akan selamanya berjalan dengan baik. Dengan kata lain perawatan merupakan suatu bagian yang tidak 
DOI: https://doi.org/10.33330/jurteksi.v6i1.429

Available online at http://jurnal.stmikroyal.ac.id/index.php/jurteksi

dapat dipisahkan dari Sistem Pakar untuk Mendiagnosis Demam Tifoid ini

\section{Tampilan Program}

Tampilan hasil implementasi sistem pakar untuk mendiagnosis demam tifoid in adalah sebagai berikut :

\section{Tampilan Form Menu Utama}

Form Menu Utama adalah form yang ditampilkan sebagai form induk dari Perangkat Lunak Sistem Pakar Demam Tipoid. Adapun isi dari form ini adalah menu-menu dengan sistem drop down yang dapat dipilih user dalam berinteraksi dengan Perangkat Lunak Sistem Pakar Demam Tipoid. Adapun gambar dari tampilan form Menu Utama dapat dilihat pada Gambar 1.

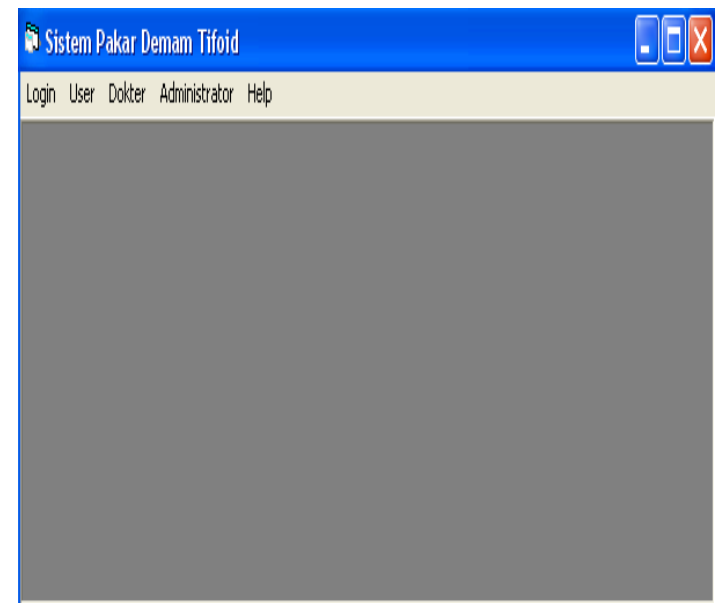

Gambar 1 : Tampilan Menu Utama

\section{Tampilan Form Login}

From Login adalah form yang ditampilkan sebagai form penerima inputan username dan password dari user yang berfungsi sebagai validasi login user yang ingin menggunakan perangkat lunak Sistem Pakar Demam Tipoid. Adapun gambar dari tampilan form Login dapat dilihat pada Gambar 2.

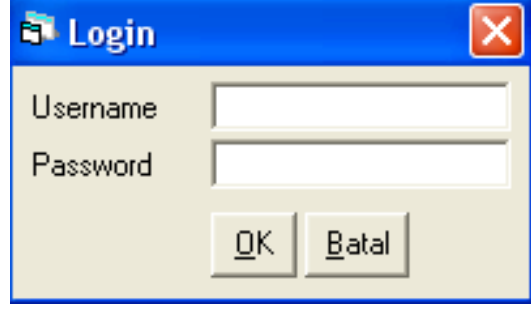

Gambar 2: Tampilan Login

\section{Tampilan Form Data Pertanyaan}

From Data Pertanyaan adalah form yang ditampilkan sebagai form penerima inputan data pertanyaan gejala-gejala penyakit yang berfungsi untuk memberikan tingkatan nilai terhadap suatu gejala penyakit pada Perangkat lunak Sistem Pakar Demam Tipoid. Adapun gambar dari tampilan form Data Pertanyaan dapat dilihat pada Gambar 3.

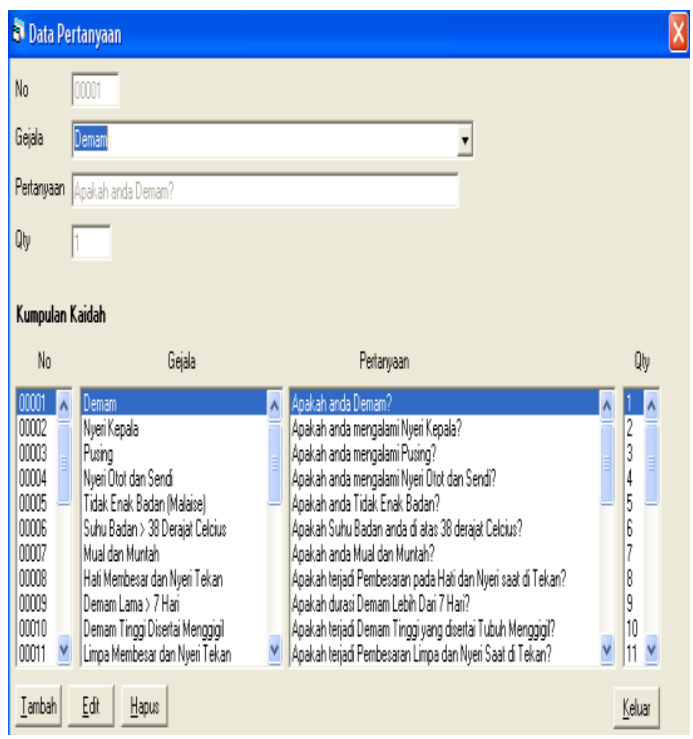

Gambar 3 : Tampilan Form Pertanyaan

\section{Tampilan Form Data Penyakit}

From Data Penyakit adalah form yang ditampilkan sebagai form penerima inputan data penyakit yang mirip dengan Demam Tipoid yang 
Vol. VI No. 1, Des 2019, hlm. 87 - 92

DOI: https://doi.org/10.33330/jurteksi.v6i1.429

Available online at http://jurnal.stmikroyal.ac.id/index.php/jurteksi

berfungsi sebagai pembanding terhadap penyakit demam tipoid. Adapun gambar dari tampilan form Data Penyakit dapat dilihat pada Gambar 4.

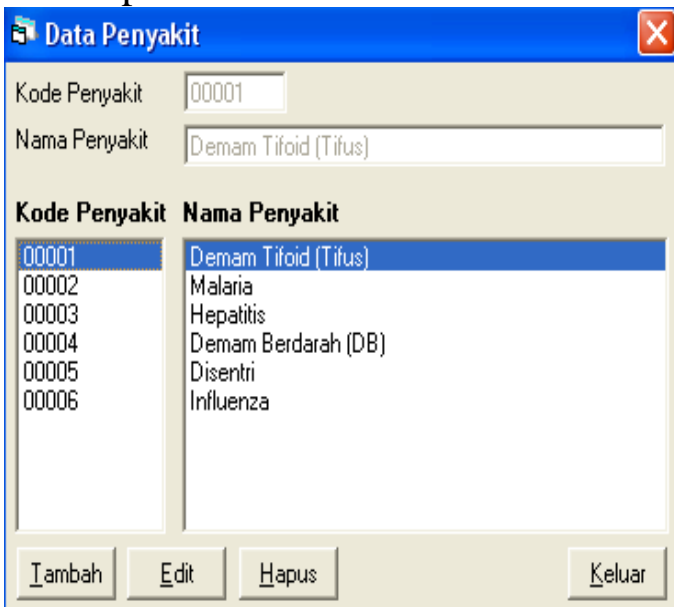

Gambar 4 : Tampilan Form Penyakit

\section{Tampilan Form Data Gejala}

From Data Gejala adalah form yang ditampilkan sebagai form penerima inputan data gejala-gejala penyakit demam tipoid atau penyakit yang mirip dengan Demam Tipoid Adapun gambar dari tampilan form Data Gejala dapat dilihat pada Gambar 5.

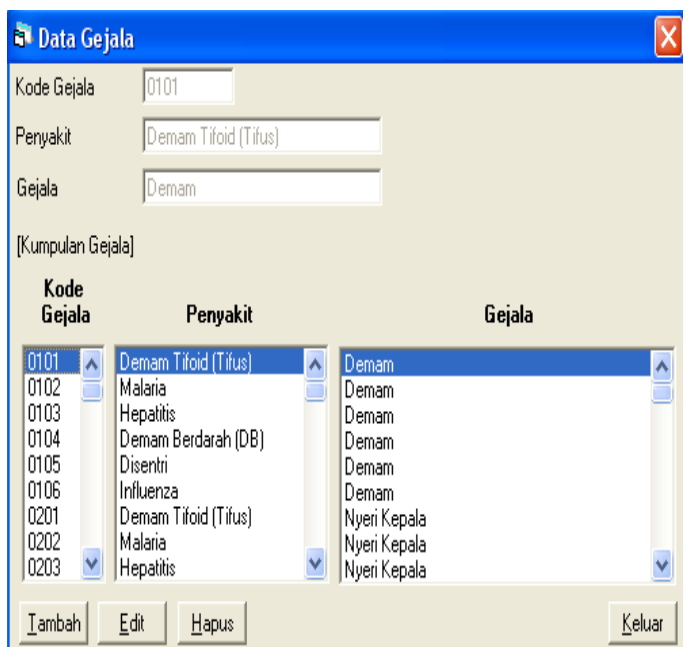

Gambar 5 : Tampilan Form Gejala

\section{Tampilan Form Data Penanganan}

From Data Penanganan adalah form yang ditampilkan sebagai form penerima inputan data penanganan terhadap penyakit yang ada di dalam database perangkat Lunak Sistem Pakar Demam Tipoid. Adapun gambar dari tampilan form Data Penanganan dapat dilihat pada Gambar 6.

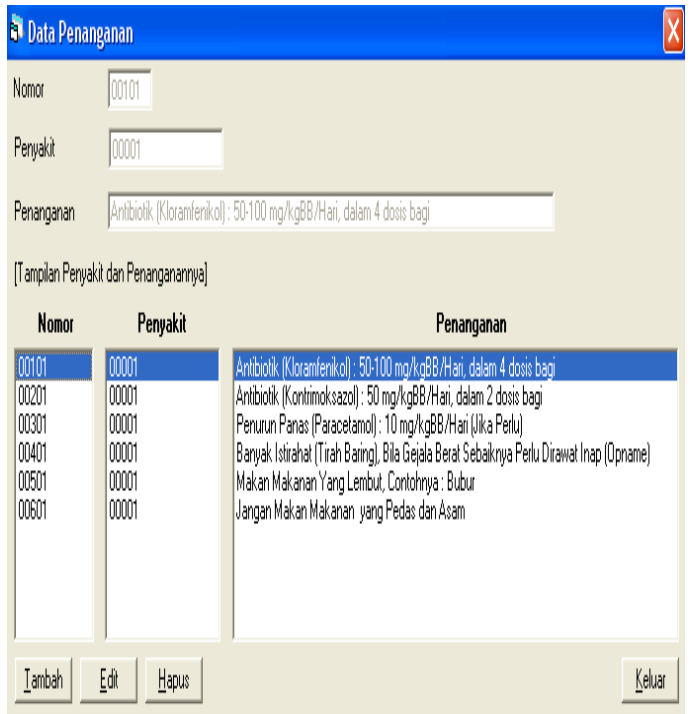

Gambar 6 : Tampilan Form Penangana

\section{SIMPULAN}

Berdasarkan hasil penelitian yang telah dilakukan, maka penulis mengambil kesimpulan sebagai berikut

1. Program sistem pakar EXTYFD digunakan untuk mendignosis penyakit demam tifoid berdasarkan gejala-gejala yang dirasakan pasien dan hasil tes laboratorium beserta saran penanganannya.

2. Proses pengumpulan pengetahuan dari seorang pakar merupakan tugas yang rumit dan tidak mudah dikumpulkan, dan sering 
DOI: https://doi.org/10.33330/jurteksi.v6i1.429

Available online at http://jurnal.stmikroyal.ac.id/index.php/jurteksi

menimbulkan kendala atau hambatan dalam pembuatan sistem pakar.

\section{DAFTAR PUSTAKA}

[1] Kusrini, 2008, Aplikasi Sistem Pakar, Penerbit PT. Elex Media Komputindo, Yogyakarta

[2] Sarwono Was Padji, 2008, Ilmu Penyakit Dalam, Penerbit BPFKUI, Jakarta.

[3] T. Sutojo. S.Si., M.Kom, Edy Mulyanto, S.Si., M.Kom dan Dr. Vincent Suhartono, 2013, Kecerdasan Buatan, Penerbit Andi, Yogyakarta.

[4] Sri Kusumadewi, 2003, Artificial Intelligence (Teknik dan Aplikasinya), Penerbit Graha Ilmu, Yogyakarta. 